\title{
Production and Characterization of Soymilk Using Locally Prepared Date Paste (Phoenix Dactylifera), White Sugar and Glycerol as Sweeteners
}

\author{
Paul SH, Adeniyi OD and Olutoye MA* \\ Department of Chemical Engineering, Federal University of Technology Minna, Nigeria \\ Submission: August 01, 2017; Published: August 21, 2017 \\ *Corresponding author: Olutoye MA, Department of Chemical Engineering, Federal University of Technology Minna, Nigeria, \\ Email: m.olutoye@futminna.edu.ng
}

Abstract

The production and characterization of soymilk using locally prepared Phoenix dactylifera pastes and glycerol as sweetener was investigated. Three equal portions of soymilk were employed and the nutritional quality was determined through proximate and sensory analyses. Key nutrient parameters such as percentage energy value, proteins value carbohydrate and glucose contents were determined and compared. The results show that soymilk prepared with date paste, white sugar and glycerol have $13.21 \%, 14.26 \%$, and $13.97 \%$ protein, while carbohydrate, glucose and energy values, $10.54 \%, 8.43 \%$ and $58.72 \% ; 4.78 \%, 4.40 \%$ and $35.86 \%$ and, 5.49\%, 5.20\% and $39.23 \%$, respectively. The medicinal and food applications revealed Phoenix dactylifera as not only an effective substitute to white sugar but also a better alternative in economy, environmental friendliness and health advantages thus, it can be concluded that it serves an effective substitute to white sugar in food applications.

Keywords: Dates; paste; Glycerol; Sugar; Soymilk; Sweetener; nutrient and health

\section{Introduction}

Date paste is an essential food substance that is produced from date palm fruits (Phoenix dactylifera) a tree believed to be the most ancient cultivated fruits plants of all plants in the world [1]. Date plants are known to be common in continents like Asia and Africa particularly in areas like the Nile River, Euphrates River, Senegal and Indus rivers in northern India, (Arabia countries) and Israel [2]. Today, date is almost cultivated and consumed all over the world because of it enormous importance and applications in the sustenance of human life. The plant's production in Nigeria started about 17 th century ago but remain subsistence because of the poor awareness on its nutritional value [3]. Dates contain essential nutrients, assimilative sugar and very high energy profile [4]. Phoenix dactylifera is one of the highest producers of energy as it gives more than 3,000Cal./ $\mathrm{kg}$ compared to cooked rice: 1,800Cal./kg, meat without fat: 2,224Cal./kg, banana: 970Cal./kg and orange: 480Cal./kg. The fruits whose fleshy mesocarp is used for the production of date paste, consists of $2 \%$ protein, $2.5 \%$ fibre, $70 \%$ carbohydrate most of which is invert sugar (fructose and glucose) absorbed easily by human body system without being subjected to digestion (enzymatic actions) as in the case of ordinary sugars (sucrose). Therefore, good for those who cannot take sucrose or, ordinary sugar [1]. Dates consist of elements like; magnesium $(\mathrm{Mg})$, calcium $(\mathrm{Ca})$, sodium $(\mathrm{Na})$, chlorine $(\mathrm{Cl})$, potassium $(\mathrm{K})$, iron $(\mathrm{Fe})$, copper $(\mathrm{Cu})$, zinc $(\mathrm{Zn})$, silicon $(\mathrm{Si})$, manganese $(\mathrm{Mn})$, sulphur (S), phosphorus (p), in different proportion and very minute amount of oil. Dates foods are good sources of vitamins A, B complex and contain high magnesium $(600 \mathrm{mg} / \mathrm{kg})$ that could be beneficial in the prevention of cancer. Dates consumers in the Sahara areas are known to have the minimal rate of cancer; a fact attributed to magnesium found in date. Dates is very rich in minerals and the fruits are used for the production of the following foods; Date paste, jam, nut roll, sweetener, soft drinks, baby diets, liquid sugar, date butter, vinegar and dates syrup. Medically date fruits when processed, are used as detersive and astringent in intestinal trouble because it contain tannin; treatment of sore throat, and cold, bronchial catarrh. It is taken to relieve fever, cystitis, gonorrhea, Edema, liver and abdominal troubles. The complexity involve in process lines for white sugar production as a sweetener, discourages small scale producers and indigenous Entrepreneurs. Also, the threat to human health posed by chemically processed food when consumed makes the search for an alternative sweetener that will substitute white sugar with better characteristics imperative which is the focus of the present research. 


\section{Methods}

\section{Materials}

The materials used for this research were obtained from Federal Cereal Research Institute Badegi. Glycerol, dates fruits, and soybeans seeds were used as raw materials among others.

\section{Preparation of date paste}

The date fruits were collected and pitted after which, the fleshy parts grinded. The next step was the addition of water (called hydrolysis). The resulting date solution was filtered using a very fine netted mesh after thorough stirring. The filtrate which contains the sugary content was then boiled for sixty minutes to eliminate microorganism and the boiled solution was concentrated to obtain sugar using evaporating pan. At this point, the molasses was further concentrated by oven drying at $120 \mathrm{oC}$ for $6 \mathrm{~h}$ and the resulting product was a sweet, dark brown, highly molten viscous semi-solid compound referred to as date paste.

\section{Preparation of soy beans milk}

The soy beans seeds $(1 \mathrm{~kg})$ were collected and soaked in boiled water for $3 \mathrm{~h}$. This was followed by crushing using mortar and pestle, and thoroughly washed to remove the seed coats. The washed seeds were then further soaked for $1 \mathrm{~h}$ before grinding thereafter, the concentrate raw soy product was further hydrated and filtered to remove coarse particles and impurities. The resultant raw milk solution was boiled with $2 \mathrm{~g} \mathrm{NaCl}$ to obtain a creamy taste eliminate some micro- organisms present. The micro-organisms that survive the salt's effect are deactivated by the application of heat via boiling (Table $1 \& 2$ )

Table 1: Results of soymilk samples after the application of the three sweeteners date paste, white sugar and pure glycerol as sweeteners.

\begin{tabular}{|c|c|c|c|}
\hline Parameters & Sample A & Sample B & Sample C \\
\hline pH & 5.85 & 6.93 & 5.86 \\
\hline Total solids (\%) & 13.24 & 9.21 & 64.35 \\
\hline Moisture content (\%) & 60.8 & 50.58 & 13.97 \\
\hline Crude protein (\%) & 13.21 & 14.26 & 0.21 \\
\hline Ash \% & 0.2 & 0.44 & 5.49 \\
\hline Carbohydrate (\%) & 10.54 & 4.78 & 39.23 \\
\hline Energy value (\%) & 58.72 & 35.86 & 5.2 \\
\hline Glucose value (\%) & 8.43 & 4.4 & 0.99 \\
\hline Phosphorous (p) mg/100ml & 0.74 & 0.83 & 2.87 \\
\hline Potassium(K) $\mathrm{mg} / 100 \mathrm{ml}$ & 2.84 & 2.23 & 0.56 \\
\hline Sodium( Na) $\mathrm{mg} / 100 \mathrm{ml}$ & 0.35 & 0.49 & 3.2 \\
\hline Calcium (Ca) $\mathrm{mg} / 100 \mathrm{ml}$ & 3.8 & 1.6 & 12 \\
\hline Magnesium( Mg) $\mathrm{mg} / 100 \mathrm{ml}$ & 15 & 6 & 8 \\
\hline Soluble solids (SS) (\%) & 10 & 10 & \\
\hline
\end{tabular}

Table 2: Show results of sensory analysis of the three samples of soymilk using 50 questionnaires'.

\begin{tabular}{|c|c|c|c|}
\hline Parameters & Sample A Frequency & Sample B Frequency & Sample C Frequency \\
\hline Sweetness & 15 & 15 & 20 \\
\hline Site appealing/color & 19 & 18 & 13 \\
\hline preference & 18 & 22 & 10 \\
\hline awareness & 10 & 50 & 18 \\
\hline uses/ applications & 8 & 12 & 30 \\
\hline
\end{tabular}

\section{Sample analysis of the prepared soymilk}

Proximate analysis was carried out on the prepared samples to determine the carbohydrate, glucose/fructose, vitamins and, protein contents. The amount protein was determined using kjedahl digestion procedure as described by the Association of Officials' Analytical Chemist report 2012 (AOAC) standard for analysis of beverages. $1 \mathrm{~mL}$ of the each sample was used with $1 \mathrm{~g}$ of kjedahl catalysts and $5 \mathrm{~mL}$ of concentrated $\mathrm{H}_{2} \mathrm{SO}_{4}$ was added. The samples were digested at temperatures of 150 oC to avoid frothing. The temperature was then adjusted steadily (50 oC) for each 30 minutes until it attains a temperature of 350 oC. The digested samples were removed from the digester cooled and distilled in a kjedahl distillation apparatus. $10 \mathrm{~mL}$ of boric acid was added to the distillate collected and was titrated against $0.1 \mathrm{M}$ of Hydrochloric acid $(\mathrm{HCl})$ to evaluate the content. Also, the determination of the minerals elements, $\mathrm{pH}$, total solid, ash, specific gravity, soluble solid, relative density, and refractive index were determined. The analysis were carried out from the diluted digest using flame photometer to obtain amounts of sodium $(\mathrm{Na})$, potassium $(\mathrm{K})$, magnesium $(\mathrm{Mg})$, and calcium (Ca). 
Furthermore, amount of phosphorus present was determined using ammonia molybdate procedures with a spectrophotometer.

\section{Results and Discussion}

\section{Results}

The sweetness of each sweetener was tested and nutritional content analyzed and compared with literature as shown below.

\section{Discussions}

From the results obtained it shows that the three samples of soymilk 'A', 'B' and 'C' has pH values of 5.85, 6.93 and 6.86 showing that even though, dates fruits have been adjudged as one of the most basic fruits by literature, has shown to be more acidic than other samples of soymilk. This phenomenon may be due to the effect of heat during the preparation of the three samples.

The results for the three samples indicated that sample ' $A$ ' (soy milk and dates paste), sample), sample 'B' (soymilk and white) and sample ' $\mathrm{C}$ ' (soymilk and pure glycerol) has $13.24 \%$, 9.21\% and 5.66 respectively indicating that sample ' $\mathrm{A}$ ' has the highest number of solids while sample ' $C$ ', has the least amount of solids which is reasonable. Sample 'B' however, remain the intermediate with value in between the samples. The results revealed that sample ' $\mathrm{A}$ ' has $60.80 \%$, sample ' $\mathrm{B}$ ' has $50.58 \%$ and sample ' $\mathrm{C}$ ' has $64.35 \%$ water. The variations in moisture content, shows that sample ' $\mathrm{C}$ ' has the highest percentage of moisture (64.35) while sample ' $\mathrm{B}$ ' has the lowest percentage of moisture (50.58) leaving sample ' $A$ ' as intermediate $60.80 \%$. The sharp differences between the three samples in moisture contents, agreed with literature that both glycerol and dates are water/retainers hydrophilic (hygroscopic) a character that cannot be attributed to white sugar. Proteins these are body building molecules with amino acids as their basics structural units. Proteins are made up of polypeptide chains some of which contain only one polypeptide chain example myoglobin while others contain more than one. The result of this analyses shows that sample 'A' has $13.21 \%$, sample 'B' has $14.26 \%$ and sample ' $C$ ' has $13.97 \%$ of proteins. This result favors sample ' $C$ ' followed by sample ' $\mathrm{B}$ ' and then sample 'A'. This analyses shows that oil was insignificant/negligible in the three samples. Ash this is the by-product of the furnace action on a substance. The results of these analyses indicate $0.20 \% 0.44 \%$ and $0.21 \%$ ash for sample $\mathrm{A}, \mathrm{B}$ and $\mathrm{C}$ respectively. Making sample 'B' the highest, followed by sample $\mathrm{C}$ and sample $\mathrm{A}$ has the least ash even though; it has the highest total solids contents. In accordance with literatures, dates and glycerol are highly soluble in water perhaps; their high solubility is responsible for this observations. Carbohydrates these are naturally occurring organic compounds containing carbon, hydrogen and oxygen. The molecular formula is given as; $\mathrm{C}_{\mathrm{x}}\left(\mathrm{H}_{2} \mathrm{O}\right)_{\mathrm{Y}}$ carbohydrates can be classified as simple or complex sugars depending on their crystalline, solubility and sweetness nature. Glucose/sucrose (simple, crystalline, soluble and sweet tasting sugar) and starch (complex, less crystalline less soluble and less sweet) respectively. These analyses indicate that sample ' $\mathrm{A}$ ' has $10.54 \%$, sample ' $\mathrm{B}$ ' has $4.78 \%$ and sample ' $\mathrm{C}$ ' has $5.49 \%$ carbohydrates sample ' $A$ ' therefore, is adjudged to have the highest amount of carbohydrate (reducing and complex sugars while sample ' $\mathrm{C}$ ' is next with $5.49 \%$ sample ' $\mathrm{B}$ ' is the least carbohydrates contents having $4.78 \%$ carbohydrates. Energy as defined by expert is the capacity/ability to do work. It is basically a function of carbohydrates in a substance. The results of this research show that sample ' $\mathrm{A}$ ' has $58.72 \mathrm{KJ} / \mathrm{g}$ energy value, sample ' $\mathrm{B}$ ' has $35.86 \mathrm{KJ} / \mathrm{g}$ and sample 'C' has $39.23 \mathrm{KJ} / \mathrm{g}$ energy value. Sample 'A' being the combination of dates pastes and soymilk, therefore has the highest amount of energy. This difference is due to the present of dates in the milk, which is said to have enormous amount of energy due to the carbohydrate/ sugar contents. Sample 'C' is the next with $39.23 \mathrm{KJ} / \mathrm{g}$ sample ' $\mathrm{B}$ ' is therefore the least energy content sample since its energy value is less than others. Glucose (dextrose)/ fructose (laevulose) are the main sources of energy in Animals and Plants tissues. They are commonly called fruits sugars even though, are found on other parts of the plants. Both sugars are usually found together in sweet fruits, juices and honey. In fact, Fructose is an isomer of glucose and they resemble each others in many ways. The results of these analyses reveal that sample 'A' has $9.43 \%$, sample 'B' has $4.40 \%$ and sample 'C' has $5.20 \%$ glucose. Since the sweetness in any carbohydrate is a function of glucose/fructose contents in it, sample ' $A$ ' is scientifically sweet than other samples. This is because; it has the highest glucose contents $(9.43 \%)$. Sample ' $\mathrm{C}$ ' therefore is next having $5.20 \%$ glucose and the least is sample 'B' having $4.40 \%$ glucose. However, the result of sensory analyses showed that sample ' $C$ ' is the sweetest followed by ' $\mathrm{A}$ ' and ' $\mathrm{B}$ ' was the last. The results indicate phosphorous in sample 'A' to be $0.74 \mathrm{mg} / 100 \mathrm{~mL}$, sample ' $\mathrm{B}$ ' $0.83 \mathrm{mg} / 100 \mathrm{~mL}$ and $0.99 \mathrm{mg} / 100 \mathrm{~mL}$. Potassium is indicated to be $2.88 \mathrm{mg} / 100 \mathrm{~mL}, 2.23 \mathrm{mg} / 100 \mathrm{~mL}$ and $2.87 \mathrm{mg} / 100 \mathrm{~mL}$ for samples $A, B$ and ' $C$ ' respectively. Sodium showed a similar trend $0.65 \mathrm{mg} / 100 \mathrm{~mL}, 0.49 \mathrm{mg} / 100 \mathrm{~mL}$ and $0.56 \mathrm{mg} / 100 \mathrm{~mL}$ for sample 'A', 'B' and sample 'C' respectively. Calcium has $3.20 \mathrm{mg} / 100 \mathrm{~mL}$, $1.60 \mathrm{mg} / 100 \mathrm{~mL}$ and $3.80 \mathrm{mg} / 100 \mathrm{~mL}$ for 'A', B and $\mathrm{C}$ samples in that order magnesium has $14.85 \mathrm{mg} / 100 \mathrm{~mL}, 7.90 \mathrm{mg} / 100 \mathrm{~mL}$ and $12.30 \mathrm{mg} / 100 \mathrm{~mL}$ in sample A, B and C respectively. Sample ' $\mathrm{A}$ ' has the more magnesium than other sample which can be trace back to the fact that dates has very high amounts of magnesium. Literature also indicated the availability of vitamin ' $\mathrm{A}$ ' and vitamin ' $\mathrm{B}$ ' complex. A sensory analysis is the use of sense organs to ascertain certain characteristics of sample like sweetness, color, etc. The result of this analysis indicated that 20 persons adjudged glycerol as the sweetest of all while 15 people each said dates paste and white sugar are the sweetest. In terms of site or color acceptability, 19 people love the dark brown color of date paste in soymilk while some 18 preferred white sugar but only 13 people accepted the colorless glycerol. For preferential consumption, 22 out of 50 persons chose white sugar 18 chose dates paste and 10 chose glycerol the reason for this been that it is most sweet while others reject it because of 
the same reasons. In terms of awareness, the 50 persons were all aware of the use of white sugar as a sweetener only 10 people were aware of dates and then 18 persons of glycerol. In terms of other uses 30 people said they know other applications of glycerol, 12 people said they know other uses of white sugar while only 8 persons could have an ideas on other application of dates paste. This is certainly because people are not aware of the contents of the date plant itself. Influence of parameters like temperature, volume, concentration of both the sweeteners and the sweetened were important factors. The figures above represent the results discussed.

\section{Effects of various parameters on the soymilk process}

Temperature has the tendency to denature the protein content of the soymilk that is why it was prepared under relatively optimum temperature to avoid the denaturing of the proteins. Mixing of both the soymilk particles and the sweeteners' molecules has and overall effects on particle distribution in the system; hence sieving with a very find/micro mesh was carried out so as to have molecules of equal sizes and weight in case of gravity considerations. The concentration of each sweeter in the soy milk may affect the results therefore; all sweeteners were measured equally at the same concentrations [4-9].

\section{Conclusion}

The composition of Soymilk used, was the same since it was prepared under the same condition. Therefore, the differences in nutritional composition of the three samples were due to sweeteners' differences. From the result over date paste has made the food standard requirement as demanded by Standard Organization of Nigeria and National Agency for Food and Drug Administration and Control.

The Result Obtained and literature findings present Phoenix dactylifera paste as not only a better substitute to white sugar (from either sugar Cane or beet), but also as a medicinal sweeter for all ages. The invert nature of it sugar, is not only a substitute sweetener but the only option for diabetic patients. The excellent striving of the sources plant in our environment, have provided us with the best solution to desertification.

\section{References}

1. Wet PF, Zaid A (1999) Origin, geographical distribution and nutritional value of date palm. A Journal of Agricultural Research 3(4): 1999.

2. Morton JF, Miami M (1987) Date: Phoenix dactylifera. Fruits of warm climate international Journal of Agricultural and food science research Saudi Arabia, pp. 1-16.

3. www.ajofai.info

4. (2011) Nutritional components of date palm and its production status in Nigeria. International journal of agricultural economics and rural developments 4(2): 2011.

5. Hyten DL, Song Q Zhu Y, Choi IY, Nelson RL, et al. (2006) Impact of genetic bottleneck on soybean genome diversity. Proc Natl Acad Sci U S A 103(45): 16666-16671.

6. Hanan J (2013) Dates: The holy fruits of Arabia. Nutrition and Food Management Oregon State University Corvallis, OR97331.

7. Hassan HA, Ganbi (2012) Production of Nutritional High quality Dates fruits syrup By Using some novel Technology approaches Nutrition and Food Science Department, Faculty of education for Home Economics and Art education, King-Abd-Elaziz University, Jeddag, Saudi Arabia. Journal of Applied Science Research 8(3): 1524-1538.

8. Janette PSE (2005) Development, Evaluation and Characterization of Protein-Isoflavone Enriched Soymilk. Department of Food Science Louisiana State University and Agricultural and Mechanical College, USA.

9. Shawn SD, Perry HD (2009) Glycerol from biodiesel Production. The new corn dairy cattle Purdue University, West Lafayette, in 47907 and ADM nutritional research Decatur in 46733. Purdueaid.1999 Origin, geographical distribution nutritional value of date Palm Fruits a Journal of agricultural research 3(4): 2-8.

\begin{tabular}{l} 
Your next submission with Juniper Publishers \\
will reach you the below assets \\
- Quality Editorial service \\
- Swift Peer Review \\
- Reprints availability \\
- E-prints Service \\
- Manuscript Podcast for convenient understanding \\
- Global attainment for your research \\
- Manuscript accessibility in different formats \\
( Pdf, E-pub, Full Text, Audio) \\
- Unceasing customer service \\
Track the below URL for one-step submission \\
https://juniperpublishers.com/online-submission.php \\
\hline
\end{tabular}

